\author{
Willem G. Weststeijn \\ University of Amsterdam \\ w.g.weststeijn@uva.nl
}

\title{
DEATH IN THE EARLY LYRIC POETRY OF VELIMIR KHLEBNIKOV
}

Death is one of the main themes, perhaps the main theme of the work of Velimir Khlebnikov. It occurs everywhere in his work, from the very first poem (1904) to his famous supersaga Zangezi (1922). For Khlebnikov death is not the result of a tragic worldview. He considers death as something which on the one hand belongs to life, but on the other has to be, and can be, conquered. The article discusses the many images of death in Khlebnikov's early poems (1904-1908). Just as in his later work death is often connected with water (drowning), love, fighting and horses.

Keywords: Velimir Khlebnikov, death, water and death, love and death, war and death.

If it is indeed true that 'the main aim of literature is the struggle with death' (Dmitrii Bykov), there is no better illustration of this maxim than the work of Velimir Khlebnikov. 'Man's victory over death,' writes Nikolai Stepanov, 'is one of the basic ideas of the poet, to which he returns again and again in his work' (Stepanov 1975: 117). Death occurs everywhere in Khlebnikov's work and may be considered one of his central, perhaps the central theme. The importance of this theme in Khlebnikov's oeuvre has been noted by a number of authors, in the first place by Dmitrii Aleksandrovich Pashkin, who devoted his dissertation to it: Феномен смерти в текстах Велимира Хлебникова: Некоторые аспекты проблемы (The Phenomenon of Death in the Velimir Khlebnikov's Texts: Some Aspects of the Problem) (Pashkin 2001).

Pashkin rightly points out that authors have discussed death in separate works by Khlebnikov, sometimes even as a leitmotiv, ${ }^{1}$ but never as a theme that pervades the poet's entire oeuvre. He is the first to do so. Considering Khlebnikov's oeuvre as in principle one text, in which all the elements have to be interpreted in connection with each other, he discusses a number of motifs that can

${ }^{1}$ He explicitly mentions Henryk Baran's article 'Пушкин в творчестве Хлебникова: некоторые тематические связи' in his book Поэтика русской литературы начала ХХ века (Москва 1993: 152-178) and Viktor Kravets' monography Разговор о Хлебникове (Киев 1998). 
be related to death. Many of them are present in the world around us: sun, sky, wind, fire, water, others, such as soul (often connected with wind) and love (connected with tornado) are abstract, some (e. g. water nymph) are derived from folklore. According to Pashkin a typical khlebnikovian death motif is пена (foam), particularly in its connection with море (sea), but also as a sign of extreme suffering (foam at the mouth). In other chapters Pashkin discusses the relation between city and death in Khlebnikov's work and, in my opinion less convincingly, the similarity between Klebnikov's thanatology and that of poststructuralists such as Maurice Blanchot and Jean Baudrillard.

In view of the list of motifs mentioned by Pashkin, it would seem that Duganov is right when he writes that for Khlebnikov life and death form an 'absolute unity'(Duganov 1990: 62) and that 'the tragic chaos and even death, as many of his works clearly show, are definitely a part of the general cosmic harmony.' (Ibidem: 110) To a certain extent Duganov is right: in Khlebnikov's work life and death form an inseparable unity, but there is more to it. In his indefatigable search for the laws of time, which can be considered an attempt to conquer time, which also means to conquer death, ${ }^{2} \mathrm{Khlebnikov}$ considers death as something that perhaps belongs to life, but at the same time as something that has to be fought and should be overcome. And he does not only fight for mankind, but also for himself. Death is not the redeemer, who saves people, especially young and innocent children, from a life full of evil and iniquity and takes them to a better world, as we learn from Khlebnikov's predecessor, the Symbolist Fedor Sologub. The concept of a better or higher world does not exist any longer for the 'Postsymbolist' Khlebnikov. For him it is a part of life, but at the same time it should not be accepted, but challenged and vanquished. The struggle with death as the evil side of life permeates Khlebnikov's entire oeuvre.

In the article referred to in note 6 I pointed out that from his early poetry Khlebnikov wrote about death and I mentioned a number of the early poems in which death plays a major role. In this article I will substantiate this claim and discuss some of these poems. I will confine myself to the poems written from 1904-1908, as they were published in the first volume of the latest edition of Khlebnikov's collected works (Khlebnikov 2000-2006).

In the very first poem, 'Странник, ты видел...', written in 1904, death is not explicitly mentioned. However, the poem describes horses that are severely suffering and do not shed tears, but foam. They are compared with the earth, which at a moment of suffering under the yoke of fate, also drops foam.

Странник, ты видел,

Как конь иногда,

Замученный, дико оком поводя,

На тихую поверхность вод голубых

Пену ронял?

2 See also the conclusion of my article 'Еще раз о композиции «Ка» Велимира Хлебникова' (Weststeijn 2020: 173). 
Ты знаешь, что кони

В страдании и муках

Пеною плачут? Слез у них нет.

Странник, [...]

Знай — это земля уронила

На лазурные воды небес

В миг страдания, - миг падения под ярмом судьбы,

Ту пену уронила,

(Khlebnikov 2000, 1: 13)

In his discussion of the motif иена Pashkin quotes some lines of the poem and comments: 'Пена маркирует не просто событие смерти, но ситуацию насильственной смерти, или подчеркивает боль, страдания, присущие умиранию.' (Pashkin 2001: 63) Further down in his text he mentions the horse as a potential dangerous animal that threatens us with death. (Ibidem: 73) In my own article 'Кони Хлебникова' (Weststeijn 2004: 331-341) I refer to studies by V. V. Ivanov and V. Ja. Propp, who show that in Indo-European and hence also Russian mythology the horse is often connected with death. A long time before Khlebnikov wrote about the First World War and the civil war, in which the horse played an enormous role, so that war, horse and death almost automatically became fused, ${ }^{3}$ the poet associated horse with death. This association had a mythological background, but not less important were Khlebnikov's ideas about the initial letters (consonants) of words. About the meaning of the letter $k$ he later writes in his article 'O простых именах языка' (1916):

$K$ начинает или слова около смерти: колоть, (по)койник, койка, конец, кукла (безжизненный, как кукла), или слова лишения свободы: ковать, кузня, ключ, кол, кольца, корень, закон, князь, круг, или малоподвижных вещей: кость, кладь, колода, кол, камень, кот (привыкающий к месту).

Закон и его книга вносят в страну покой, как и его источник: князь.

Покой всадника дан конем; покой инока келией. Рабочему покой дается концом работы. Частицы в камне не двигаются. Исчезновение движения содержание $K$-имени; ему довольно близко действие сложения.

Ограничивающий место край дает красоту, кровь (скрытую), крысу (кроющееся существо). (Khlebnikov 2005, 6/1: 119-120)

The Russian word for horse, конь, is also mentioned in this article, associated with death by means of покой (rest), but also, of course, by means of other words that are similar in sound such as конеи and окончить.

In the poem 'Мирооси данник звездный...' there is not a direct image of death, but the lyric I exposes itself to great danger in order to become a poet (to learn the words):

Пролетая в миг над бездной,

Задевая краем бездны,

Я учусь словесо.

(Khlebnikov 2000, 1: 15)

3 As for instance in 'Конь гражданской войны, наклоняя желтые зубы, рвал и ел траву людей.' From Малиновая щиащка (Khlebnikov 2004, 5: 207). 
In the next poem, 'Гробатая явь' the possible relation between the poet (here described as 'будрое дитя', child of the future) and death is made explicit. The child denies that it will die, 'become a sack full of worms'. On the contrary, it will have a brilliant future and will become the leader of the cavalry of the stars.

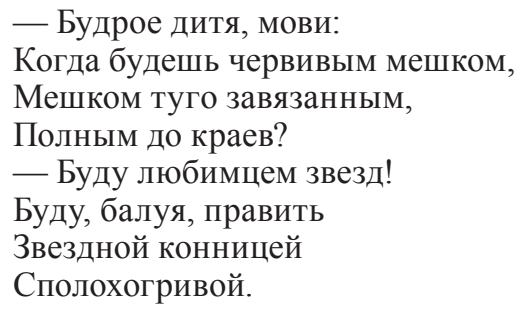

(Khlebnikov 2000, 1: 17)

Just as in the preceding poem Khlebnikov does not describe the lyric I or the speaker as an ordinary human being, but as someone - in these early poems a child - who is on a higher level, that of the universe, the stars (see also the poems 'Мировик' - Собр. соч. 1: 23 and 'И я свирел в свою свирель...' Khlebnikov 2000, 1: 51). This elevation of the lyric I - in Khlebnikov's later poetry it is sometimes presented as a prophet, sometimes even as a god - is typical for the poet's entire oeuvre. ${ }^{4}$

If we follow Pashkin, who describes motifs such as water, river, water nymph and foam as connected with death, the poem 'Русалка телом голубым...' decidedly would suggest death.

Русалка телом голубым
Немоб осенних красоту
Воспеть хотела.
Туда, о, к ней! Туда, о, к ним!
И вмиг в реке! И вмиг в волну!
Туда, где рень! Туда, где пена!
Но где же цель? Но где же тело?
Но где же плен? Но где полон?
Она, она, о ужас слышу, — зеленая жена!
И вопль ее, толпа испугом -
О ужас, ужас, о сором!..

(Khlebnikov 2000, 1: 32)

The same image of a 'beautiful girl of the water' and her possibly tragic fate we find in the next poem;

Плескиня, дева водных дел, радея красоте, Играла и сияла, служила немоте

И крыльными грустильями воздела темноте.

(Khlebnikov 2000, 1: 33)

4 See my articles (Weststeijn 1986: 217-242; 1987: 119-139). Both articles are also published in (Weststeijn 2020). 
The combination 'water' and 'tragedy' we also find in the poems 'Дувь волн холодных моря...' (Khlebnikov 2000, 1: 48) and 'Моют, моют валуны...' (Khlebnikov 2000, 1: 72). In the first poem the cold water of the sea is linked with woe (горе), in the second one a boat goes down:

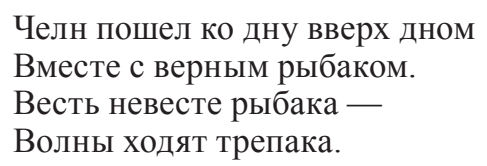

A boat that is sinking or capsizing often occurs in Khlebnikov's work. Another example in his early poetry is ‘Зеловеков венок...' (Khlebnikov 2000, 1: 154):

В безраздумные хляби челнок унесло.
О, не умер бы он!
О, боюсь за него!

When Khlebnikov writes about love he often combines it, directly or indirectly, with death. One of his first poems in which we find this combination is the four-line poem 'Гроб леунностей младых...' (Khlebnikov 2000, 1: 53):

Гроб леунностей младых.

Веко милое упало.

Смертнич, смертнич, свет-жених,

Я весь сон тебя видала.

The combination 'love' and 'grave' also occurs in the poem 'Мне видны Рак, Овен...' ('В эту ночь любить и могила могла...' - Khlebnikov 2000, 1: 127). In 'Стрелок, чей стан был узок...' a hunter is killed by Diana; in 'Козак' love is accompanied by blood and violence.

Despite the frequency of death motifs in his work, one cannot say that Khlebnikov has a tragic worldview. On the one hand he seeks to overcome death, but on the other he realizes that death belongs to life and also realizes, albeit unconsciously, that the introduction of death motives and the opposition between life and death into an even short poem makes such a poem just more 'interesting'. Hence the various ways in which death occurs in his work. I already discussed death in connection with severe suffering, mortal danger, drowning, being frightened and love, but there are other employments of the motif. One of them is the more or less logical introduction of death when a fight is described. Since the First World War Khlebnikov often wrote about battles and fighting, but we find the theme already in his early poetry. In the poem 'От Косова я - дружины свой бег...' he refers in the first strophe to the victory of the Turks over the Serbian-Bosnians in the battle on the field of Kosovo in 1389, in the second to the defeat of the Teutonic horde against the Polish monarch Vladislav II in 1410.

От Косова я - дружины свой бег

Злой продолжали на трупах.

Ворог колол, резал и сек

Павших от ужаса, глупых. 
От Грюнвальда - истуканы

С серым пером на темени,

В рубахах медных великаны

Бились с рожденным на Немане.

(Khlebnikov 2000, 1: 98)

The poem 'Скифское' also goes back to the past and is full of fighting and death (and horses):

И жизнь иль смерть - любое,

И алчут кони боя.

И в межи роя узких стрел -

Пустили их стрелки -

Бросают стаи конских тел

Нагие ездоки.

[...]

И конь, чья ярь испытана,

Грозит врагу копытами.

Свирепооки кони,

И кто-то, кто-то стонет.

И верная подруга

Бросается в траву.

Разрезала подпругу,

Вонзила нож врагу.

(Khlebnikov 2000, 1: 193-195)

The sword belongs to war and death. For Khlebnikov the relationship between sword and death is also evident as the two words in Russian, мeч and смерть (мертвеи) are similar in sound. ${ }^{5}$

И есть ли что мечей поюнней?

Но чу! везде полет воюний.

Они везде зовут в борель,

И смерть - красивая свирель.

О, меч, по выйному пути бегач,

Ты - неутомчивый могач!

Везде преследует могун!

Везде преследуем бегун!

Печальны мертвых улыбели,

Сияльны неба голубели.

(Khlebnikov 2000, 1: 180)

Interesting in this poem is the fourth line, in which death is compared with a beautiful flute. It is one of Khlebnikov's daring and original images - it also

5 The same holds true for мор and мертвенный, as for instance in the poem 'Землявых туманов умчался собор...' (Khlebnikov 2000, 1: 64). 
occurs in the poem 'Равнец! скажи, зачем борель...' in the line 'Свирелью смерть взял веселоша' (Khlebnikov 2000, 1: 178) — which sets him apart from other poets. Another of these original images we find in the well-known poem 'Из мешка...', in which the world is compared with the sneer on the mouth of a hanged person.

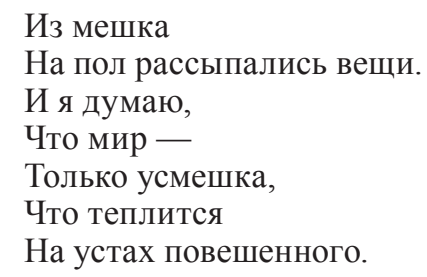

(Khlebnikov 2000, 1: 171)

In a number of his early poems Khlebnikov personifies death. In one of them kissing death purses its lips ('Смехлые уста смерть протянула целующая' - Khlebnikov 2000, 1: 107), in another one ('Опыт жеманного' — Khlebnikov 2000, 1: 135) death walks with a basket.

The poems discussed in this article form only a small part of Khlebnikov's work. They were all written at a time when Symbolism was still dominant in Russian literature and testify to the great originality of the poet, both as regards form (language) and content. Death is a major theme in them. It occurs as a result of strife or as the inevitable accompaniment of love and is connected with a number of motifs, many of which have to do with water. It functions in comparisons and metaphors and is personified. All the ways in which death manifests itself in the early poems are also present in Khlebnikov's later work. It is a clear indication that this work may indeed be considered a unity, in which all the separate parts are closely connected with each other and are best interpreted in the context of the entire oeuvre.

\section{REFERENCES}

Weststeijn Willem G. "The Role of the 'I' in Chlebnikov's Poetry (On the Typology of the Lyrical Subject)", Weststeijn Willem G. (ed.). Velimir Chlebnikov (1885-1922): Myth and Reality. Amsterdam: Rodopi, 1986: 217-242.

Weststeijn Willem G. "Die Mythisierung des lyrischen Ich in der Poesie Velimir Chlebnikovs". Wiener Slawistischer Almanach. Sonderband 20. Mythen in der slavischen Moderne. Wien: Gesellschaft zur Förderung slawistischer Studien, 1987: 119-139.

Weststeijn Willem G. “Кони Хлебникова”. Russian Literature LVI-I/II/III (2004): 331-341.

Weststeijn Willem G. “Еще раз о композиции 'Ка' Велимира Хлебникова”. Weststeijn Willem G. Filling the Unfathomable Full of the Unknown. Amsterdam: Pegasus, 2020: 167-175. Weststeijn Willem G. Filling the Unfathomable Full of the Unknown. Amsterdam: Pegasus, 2020.

Баран Хенрик. «Пушкин в творчестве Хлебникова: некоторые тематические связи». Баран Хенрик. Поэтика русской литературы начала ХХ века. Москва: Прогресс, 1993.

Дуганов Рудольф. Велимир Хлебников: Природа творчества. Москва: Советский писатель, 1990. 
Кравец Виктор. Разговор о Хлебникове с приложением «Изборника» 1914 г. Киев: РВЦ Проза, 1998.

Пашкин Дмитрий. Феномен смерти в текстах Велимира Хлебникова: Некоторые аспекты проблемы. Диссертация. Тюмень: Тюменьский государственный университет, 2001.

Степанов Николай. Велимир Хлебников. Жизнь и творчество. Москва: Советский писатель, 1975.

Хлебников Велимир. Собрание сочинений в шести томах. Сост., подг. текста и примечания Е. Р. Арензона и Р. В. Дуганова. Москва: ИМЛИ РАН, 2000-2006.

\section{REFERENCES}

Baran Henrik. "Pushkin v tvorchestve Hlebnikova: nekotorye tematicheskie svyazi". Baran Henrik. Poetika russkoj literatury nachala XX veka. Moskva: Progress, 1993.

Duganov Rudol'f. Velimir Hlebnikov: Priroda tvorchestva. Moskva: Sovetskij pisatel', 1990.

Kravec Viktor. Razgovor o Hlebnikove s prilozheniem "Izbornika” 1914 g. Kiev: RVC Proza, 1998. Pashkin Dmitrij. Fenomen smerti v tekstah Velimira Hlebnikova: Nekotorye aspekty problemy. Dissertaciya. Tyumen': Tyumen'skij gosudarstvennyj universitet, 2001.

Stepanov Nikolaj. Velimir Hlebnikov. Zhizn' i tvorchestvo. Moskva: Sovetskij pisatel', 1975.

Hlebnikov Velimir. Sobranie sochinenij $v$ shesti tomah. Sost., podg. teksta i primechaniya E. R. Arenzona i R. V. Duganova. Moskva: IMLI RAN, 2000-2006.

Weststeijn Willem G. "The Role of the 'I' in Chlebnikov's Poetry (On the Typology of the Lyrical Subject)", Weststeijn Willem G. (ed.). Velimir Chlebnikov (1885-1922): Myth and Reality. Amsterdam: Rodopi, 1986: 217-242.

Weststeijn Willem G. "Die Mythisierung des lyrischen Ich in der Poesie Velimir Chlebnikovs". Wiener Slawistischer Almanach. Sonderband 20. Mythen in der slavischen Moderne. Wien: Gesellschaft zur Förderung slawistischer Studien, 1987: 119-139.

Weststeijn Willem G. "Koni Hlebnikova”. Russian Literature LVI-I/II/III (2004): 331-341.

Weststeijn Willem G. "Eshche raz o kompozicii 'Ka' Velimira Hlebnikova”. Weststeijn Willem G. Filling the Unfathomable Full of the Unknown. Amsterdam: Pegasus, 2020: 167-175.

Weststeijn Willem G. Filling the Unfathomable Full of the Unknown. Amsterdam: Pegasus, 2020.

Вилем Вестстејн

СМРТ У РАНОЈ ЛИРСКОЈ ПОЕЗИЈИ ВЕЛИМИРА ХЛЕБЊИКОВА

Резиме

Смрт је једна од главних, а можда и главна тема у стваралаштву Велимира Хлебњикова. Присутна је у његовом целокупном раду, од прве песме (1904), све до познате натповести Зангеези (1922). За Хлебњикова смрт није резултат трагичног погледа на свет. Он сматра да је смрт нешто што, с једне стране, припада животу, али је, с друге стране, нешто што мора и може бити побеђено. У раду се разматрају многобројне слике смрти у раним песмама Хлебњикова (1904-1908). Баш као и у његовим каснијим радовима, смрт је неретко везана за воду (утапање), љубав, борбу и коње.

Кључне речи: Велимир Хлебњиков, смрт, вода и смрт, љубав и смрт, рат и смрт. 